\title{
THE BEHAVIOR OF THE CROWD FROM THE POSITION OF SOME AUTHORS
}

DOI: http://doi.org/10.15350/UK_6/9/4

Anastasia Titova ${ }^{1}$

Elena Kalabina ${ }^{2}$

\section{Abstract}

A person who is in the crowd, keenly feels the mood of a neighbor, moreover, it is automatically transmitted to him. The individual no longer behaves as an individual, he is literally "infected" by the mood of the crowd. This phenomenon is called "crowd psychology".

Key words: crowd, behavior, people, character, theory, psychology, group.

Каждый человек обладает определенным характером, привычками и ведет установившийся образ жизни. И таких людей большинство, так как их жизнь принято считать повседневной нормой. Однако есть и определенные личности или же группы людей, которые силой воли, своим желанием и энтузиазмом могут заставить других людей выполнять определенную роль. Человек, находящийся в толпе, остро чувствует настрой соседа, более того, он автоматически передается и ему. Индивид уже не ведет себя как отдельная личность, он в буквальном смысле слова «заражается» настроением толпы. Этот феномен носит название «психология толпы».

Некоторые из наиболее важных теорий, касающихся поведения толпы, таковы:

1. Теория Ле Бона;

2. Теория Макдугалла;

3. Теория Фрейда;

4. Теория Олпорта;

5. Теория Тернера.

\section{1. Теория Ле Бона:}

Согласно Ле Бону, самому раннему и главному исследователю поведения толпы, индивид уступает "инстинктам, которые, будь он один, он волей-неволей держал бы в узде". Подобно загипнотизированному человеку "он больше не осознает своих действий. В то же самое время, когда некоторые способности разрушаются, другие могут быть доведены до высокой степени экзальтации. Он больше не является самим собой, но стал автоматизмом, который перестал руководствоваться своей волей. В толпе он варвар. Он обладает спонтанностью, жестокостью, свирепостью, а также энтузиазмом и героизмом примитивных существ". Объясняя поведение толпы, Ле Бон развил

\footnotetext{
${ }^{1}$ Anastasia TITOVA, student, Voronezh State University, Russia.

2Elena KALABINA, student, Voronezh State University, Russia.
} 
свое самое важное понятие "групповой разум". Групповой разум заставляет людей чувствовать, думать и действовать совершенно иначе, чем каждый индивид чувствовал бы, думал и действовал там, где он находится в состоянии изоляции. Идеи Ле Бона можно резюмировать следующим образом:

1) толпы возникают благодаря существованию анонимности (что позволяет снизить личную ответственность);

2) в заражении (идеи быстро движутся через группу;

3) через внушаемость. В толпе индивидуальная психология подчинена "коллективному менталитету", который радикально трансформирует индивидуальное поведение. Ле Бон говорил, что в периоды социального упадка и распада обществу угрожает господство толпы.

\section{2. Теория Макдугалла:}

Теория поведения неорганизованных групп или толпы, предложенная психологом Уильямом Макдугаллом, практически совпадает с теорией Ле Бона, который объясняет два центральных феномена поведения толпы, а именно усиление эмоций в толпе и снижение интеллектуального уровня, следующим образом: первый обусловлен принципом прямой индукции эмоций посредством "примитивной симпатической реакции". Он говорит, что чем больше людей, у которых можно одновременно наблюдать одни и те же эмоции, тем сильнее заражение. Индивид под влиянием эмоций теряет силу критики и впадает в ту же эмоцию. Коллективная эмоция усиливается в результате взаимного взаимодействия. Усиление эмоций и неподготовленность к противостоянию авторитету толпы, в свою очередь, тормозят интеллектуальные процессы и снижение интеллектуального уровня в толпе. Макдугалл описал поведение толпы следующими словами: Толпа " чрезмерно эмоциональна, импульсивна, непостоянна, непоследовательна, нерешительна и экстремальна в действии, проявляя только грубые эмоции и менее утонченные чувства; чрезвычайно внушаема, небрежна в обдумывании, поспешна в суждениях, неспособна к чему-либо, кроме простых и несовершенных форм рассуждения; легко поддается влиянию и влиянию, лишена самоуважения и чувства ответственности. Поэтому его поведение подобно поведению непослушного ребенка или дикого зверя.

\section{3. Теория Фрейда:}

Теория Макдугалла о симпатической индукции для объяснения усиления эмоций принимается не всеми учеными. Зигмунд Фрейд в своем эссе о групповой психологии и анализе эго замечает: "нет сомнения, что в нас существует нечто такое, что, когда мы начинаем осознавать признаки эмоций; как часто мы не можем успешно противостоять им, сопротивляться эмоциям и реагировать совершенно противоположным образом? Почему же мы всегда поддаемся этой заразе, когда находимся в группе? - Фрейд связывает это с нашими косвенными импульсами. Фрейд предполагает, что то, что 
удерживает любую группу вместе, - это любовные отношения, то есть эмоциональные связи. Это объясняет то, что он считает "главным феноменом групповой психологии".

\section{4. Теория Олпорта:}

Олпорт также критиковал теорию Макдугалла о симпатической индукции эмоций и поведения. Он предложил объяснение поведения толпы двумя принципами, одним из которых является принцип социальной фасилитации.

Согласно этому принципу, общий стимул подготавливает двух индивидуумов к одному и тому же ответу, и когда они к этому готовы, вид одного из них освобождает и усиливает этот ответ в другом. Второй принцип-интерстимуляция.

\section{5. Теория Тернера:}

Социолог Ральф Тернер вышел за рамки неадекватного психологического объяснения поведения толпы и разработал эмерджентную нормальную перспективу. Центральный тезис этой точки зрения состоит в том, что даже в самых жестоких и опасных толпах существует также социальное взаимодействие, в котором определяется ситуация, возникают нормы санкционирующего поведения, обосновываются и согласовываются направления действий.

Таким образом, все вышеприведенные объяснения проливают свет на тот или иной фактор сложного феномена поведения толпы. Как таковые, они являются неполными и недостаточными. Существует множество факторов, таких как анонимность, стимуляция, эмоциональность, внушаемость, инициация, заражение, отсутствие воли, сила бессознательных импульсов и т. д., которые отвечают за возникновение типичного поведения толпы.

Теория поведения толпы отошла от старой перспективы (Макдугалл, Ле Бон и др.), который рассматривал индивида как находящегося под влиянием толпы и теряющего способность к рациональному суждению перед лицом всепоглощающей эмоциональной заразы. Вместо этого социологи теперь объясняют поведение толпы теми же социологическими концепциями, которые объясняют поведение социальных групп.

References:

[1] Pochebut, Lyudmila Georgievna. Social community. Psychology of the crowd, society, ethnos / L. G. Pochebut; S.-peterb. state Univ .-SPb. : Publishing house of St. Petersburg. UN-TA, 2005 - 285, [1] p.

[2] The psychology of the crowd: Social. and polit. mechanisms of influence on the masses in / Comp. K. Korolev .- M.; SPb. : EKSMO: Terra fantastica, 2003 .— 792, [2] p. 